\title{
ROLE OF INSTITUTIONAL CREDIT FOR AGRICULTURAL DEVELOPMENT IN BIHAR
}

\author{
Arvind Kumar Srivastava*
}

\begin{abstract}
Naturally endowed with fertile soil, adequate rainfall, rich water resources and congenial climate, Bihar is poised for high farm productivity to lead the second green revolution in the country. Realising its importance, Government of Bihar adopted planned approach of agriculture development through Agriculture Road Maps since 2008. It aims to increase production and productivity of food crops in a cost-effective manner and make it a viable means of livelihood. The approach has put considerable emphasis on ensuring availability of certified seeds at subsidised rate, creating storage space, promoting bio-farming, farm mechanisation and new technique of System of Rice Intensification (SRI) cultivation.
\end{abstract}

Although, institutional credit assumes utmost importance in increasing agricultural productivity, the role of formal credit delivery system in the State of Bihar has not been quite encouraging. The Credit Deposit (CD) ratio in Bihar stood at 44.03 per cent as in March 2015 against the national average of 78 per cent. The State Annual Credit Plan (ACP) target of ₹0.74 lakh crore (including Non-priority Sector) and target of agriculture and allied activities at ₹0.36 lakh crore for 2014-15 works out to less than ₹6800 percapita credit.

Given the high credit elasticity of 0.574 in Bihar's agriculture, there is an urgent need to strengthen the institutional credit delivery system by encouraging all banks, particularly commercial banks, to play their role in the right earnest to secure agricultural prosperity in the State. The way forward in this regard is suggested in the paper.

\section{Introduction}

Agriculture plays an important role in Indian economy and society. In the State of Bihar it assumes all the more importance given the fact that post-division of the State in the year 2000 , ind ustry and service sectors have virtually been non-existent as also the quality of itsland and water resources can do wonders for

*Faculty Member, BIRD (NABARD), Lucknow, PIN-226012. E-mail: arvind.srivastava@nabard.org. 
agriculture growth. Although, some steps have been initiated by the State government and credit agencies in this regard in recent past, much more needs to be done. This paper presents the situation of agriculture development in the State in the recent past and analyses initiatives taken by the State government as also the role played bycredit agencies in this regard. The way forward for agricultural development in the State with specific role of institutional credit is elaborated in the paper.

\section{Objectives}

The broad objective of the paper is to assess the agricultural development of the State of Bihar and bring out initiatives taken by important stakeholders viz., Government of Bihar and credit agencies in the State.

The specific objectives of the paper are to analyse (a) the importance of agriculture development in the State consequent upon reorganisation (b) the potential of agriculture development in the State (c) initiatives taken by the State government (d) the role played by credit agencies and suggest the way forward with specific role of institutional credit agencies in this regard.

\section{Methodology}

The data used in the paper are drawn from various sources like websites of Reserve Bank of India, departments of government of Bihar and also the State Level Bankers Committee (SLBC) of select States like Bihar, Jharkhand, West Bengal and Odisha. The information was also collected from available publications of agencies like NABARD as well as informal discussions with those concerned. Various reports brought out by government agencies and academicians were also referred to have a better understanding of the issues. The data and information have been analysed to meet the objectives of the paper.

\section{Bihar - Salient Geographical Features}

Bihar, after its bifurcation in the year 2000 , has a geographical area of 93.60 lakh hectares (ha) and is divided into two parts, by the river Ganges. North Bihar having an area of 52.48 lakh hectares falls under agro-climatic zones of North West and North East alluvial plains.South Bihar, having an area of 41.12 lakh hectares, is located in agro-climatic zone of south Bihar alluvial plain. The entire State is covered with a number of river basins, 14 in all. The soil is generally fertile throughout the State and all parts of the State receive more than $1000 \mathrm{~mm}$ rainfall.

In a nutshell, good soil, adequate rainfall, sufficient water resources, and congenial temperature regime characterise the geography and agro-climatic conditions of Bihar State. All these factors point to very high agricultural production potential of the State. However, the same has not been exploited leading to the State still having low agricultural productivity in the country.

\section{Area under Cultivation and Operational}

Holding: The total population of the State was 10.41 crore constituting 8.6 per cent of total Indian population as per 2011 Census. The rural population was 9.20 crore (about 88.4 per cent). 
During 2011-12, the State had a net sown area of 53.96 lakh hectares with gross sown area as 76.47 lakh hectares resulting in the cropping intensity of 142 per cent. The valuable agriculture tracts of Bihar are Buxar, Bhojpur, Siwan, Gopalganj and Madhepura districts with net sown area exceeding 70 per cent of their geographical area.

Asper Agriculture Census 2010-11, Bihar had a total of 16.19 million operational landholdings, which wassecond in number only to Uttar Pradesh in the country (Table 1).

Table 1: State-wise Number and Area of Operational Holdings in Select States (Number in ‘000) (Area in ‘000 ha)

\begin{tabular}{lcclc}
\hline \multicolumn{1}{c}{ State } & \multicolumn{2}{c}{$2005-06$} & \multicolumn{2}{c}{ 2010-11 } \\
\hline Uttar Pradesh & Number & Area & Number & Area \\
Bihar & 14458 & 17906 & 23325 & 17622 \\
Maharashtra & 13716 & 6251 & 16191 & 6388 \\
Madhya Pradesh & 7908 & 20005 & 13699 & 19767 \\
West Bengal & 6992 & 15994 & 8872 & 15836 \\
\hline
\end{tabular}

Source: Agriculture Census, 2010-11, Government of India.

As shown in Table 1,the increase in area of operational holdings in Biharcan be attributed to inclusion of some area under cultivation which hitherto remained uncultivated as also completion of fieldwork relating to reporting of operational holdings (for Agriculture Census 2010-11) in the State after 1980-81.

The average size of landholding in the State was extremely low at 0.39 ha compared to many agrarian States in the country, having reduced further from 0.42 ha during 2005-06. The marginal farmers in the State were operating very small holdings with average size of holdings of these farmers at 0.25 ha compared to 0.39 ha of such farmers in the country. The position of average size of holdings among various categ ories of farmers in the State vis-a-vis other select States is given in Table 2.

Table 2: Average Size of Holding for Various Categories of Farmers in Select States (ha)

\begin{tabular}{lcccccc}
\hline \multicolumn{1}{c}{ States } & Marginal & Small & $\begin{array}{c}\text { Semi- } \\
\text { Medium }\end{array}$ & Medium & Large & All Size \\
\hline UttarPradesh & 0.39 & 1.40 & 2.72 & 5.52 & 15.01 & 0.76 \\
Bihar & 0.25 & 1.25 & 2.59 & 5.09 & 14.45 & 0.39 \\
Maharashtra & 0.47 & 1.42 & 2.67 & 5.62 & 15.96 & 1.44 \\
\hline
\end{tabular}


Table 2 (Contd....)

\begin{tabular}{lcccccc}
\hline \multicolumn{1}{c}{ States } & Marginal & Small & $\begin{array}{c}\text { Semi } \\
\text { Medium }\end{array}$ & Medium & Large & All Size \\
\hline MadhyaPradesh & 0.49 & 1.42 & 2.73 & 5.76 & 15.77 & 1.78 \\
West Bengal & 0.49 & 1.59 & 2.73 & 4.85 & 316.20 & 0.77 \\
All India & 0.39 & 1.42 & 2.71 & 5.76 & 17.38 & 1.15 \\
\hline
\end{tabular}

Classification of Farm Size: Marginal: up to 1 ha; Small: 1-2 ha; Semi-medium: 2-4 ha; Medium: 4-10 ha and; Large: more than 10 ha.

Source: Agriculture Census, 2010-11, Government of India.

As depicted in Table 2, the average size of operational holdings in the State of Bihar among all categories of farmers was generally lower than the size of operational holdings in select States. Keeping in view the preponderance of small farm holdings, particularly the marginal farmers who accounted for 91 per cent of operational land holdings (numbering 14.74 million) covering 36.69 lakh hectares constituting 57 per cent of total operation area, a special strategy would be required to cover farmers in the State for credit under institutional fold.

Cropping Pattern, Production and Productivity: The cropping pattern in Bihar is very much tilted in favour of subsistence sector with more than 90 per cent of area under food-grains in 201314. The share of cereals was about 86 per cent with rice occupying around 45 per cent of acreage under cultivation. Pulses were being grown in about 7 per cent area during 2013-14. Besides cereals and pulses, farmers also cultivate oilseeds, fibres, fruits and vegetables. Bihar ranks third in respect of vegetable production (Handbook of Horticulture, 2014) and vegetables are transported even to far-off States in the country. In view of increase in demand for flowers, some farmers have also evinced interest in floriculture in some parts of the State such as Gaya,J ehanabad,M uzaffarpur,Vaishali,etc.

The cereal production in the State has witnessed a quantum jump from 96.16 lakh tonnes in 2009-10 to 157.16 lakh tonnes in 2013-14. The details of production and productivity of major crops in the State are given in Table 3.

Table 3: Production and Productivity of Major Crops in Bihar (2005-14)

\begin{tabular}{lcccccc}
\hline \multicolumn{1}{c}{ Crop } & \multicolumn{2}{c}{ Production ('000 tonnes) } & \multicolumn{3}{c}{ Productivity (Kg/ha) } \\
\hline 2009-10 & $2013-14$ & $\begin{array}{c}\text { CAGR } \\
\text { (per cent) }\end{array}$ & $\begin{array}{c}\text { Triennium } \\
\text { Average } \\
\text { (2005-08) }\end{array}$ & $\begin{array}{c}\text { Triennium } \\
\text { Average } \\
\text { (2011-14) }\end{array}$ & $\begin{array}{c}\text { \% change } \\
\text { between } \\
\text { Trienniums }\end{array}$ \\
\hline Rice & 3640.16 & 6649.59 & 24.46 & 1284 & 2365 & 84.2 \\
Wheat & 4403.80 & 6134.68 & 8.93 & 1915 & 2900 & 51.5 \\
Maize & 1544.44 & 2904.24 & 16.54 & 2549 & 3870 & 51.8 \\
\hline & & & & & & (Contd...)
\end{tabular}

Journal of Rural Development, Vol. 36, No. 1, January - March : 2017 
Table 3 (Contd....)

\begin{tabular}{lcccccc}
\hline \multicolumn{1}{c}{ Crop } & \multicolumn{2}{c}{ Production ('000 tonnes) } & \multicolumn{3}{c}{ Productivity (Kg/ha) } \\
\hline & $2009-10$ & $2013-14$ & $\begin{array}{c}\text { CAGR } \\
\text { (per cent) }\end{array}$ & $\begin{array}{c}\text { Triennium } \\
\text { Average } \\
(2005-08)\end{array}$ & $\begin{array}{c}\text { Triennium } \\
\text { Average } \\
(2011-14)\end{array}$ & $\begin{array}{c}\% \text { Change } \\
\text { between } \\
\text { Trienniums }\end{array}$ \\
\hline $\begin{array}{l}\text { Coarse } \\
\text { Cereals }\end{array}$ & 1572.32 & 2932.03 & 16.29 & 1956 & 3770 & 92.8 \\
$\begin{array}{l}\text { Total } \\
\text { Cereals }\end{array}$ & 9616.28 & 15716.30 & 16.13 & 1493 & 2722 & 82.3 \\
\hline
\end{tabular}

Source: Economic Survey- Bihar, 2014-15.

As shown in Table 3 above, the average productivity figures of major cereals for triennium covering 2011-14 were $2365 \mathrm{~kg} / \mathrm{ha}$ for rice, $2900 \mathrm{~kg} / \mathrm{ha}$ for wheat and $3870 \mathrm{~kg} / \mathrm{ha}$ for maize and the productivity of these three crops increased by more than 50 per cent (more than 80 per cent in case of rice) compared to the triennium covering 2005-08. Notwithstanding this substantial increase, the productivity of major crops viz., paddy and wheat were well below not only the national average but also the average of States of eastern region.As per Special Task Force report, "Even though the State is rich in soil and water resources, the average yields of rice, wheat and maize in the State are only about 32,44 and 40 per cent, respectively, of potential yields" (Special Task Force,Government of India,2008).

\section{Dependence on Agriculture and Low Per Capita} Income in Bihar: The State has very low level of urbanisation and more than 88 per cent of the population reside in rural areas as mentioned earlier.Absence of non-agricultural enterprises in rural areas has resulted in more than 80 per cent of the population being engaged in agriculture, much higher than national average. The dependence of such a high level of population coupled with low productivity in agriculture has led to quite a high level of poverty, unemployment and overall poor economic health of the State.

It would not be out of place to mention that the State is extremely densely populated with more than 1100 persons living per sq. $\mathrm{km}$. According to the Planning Commission, 33.7 per cent of the State population lived below the poverty line in 2011-12. Agriculture being the mainstay of State's economy, it has a major role to play in ameliorating the conditions of rural poor.

In recent times, Bihar economy has shown strong and sustained growth and the annual rate of growth of Gross State Domestic Product (GSDP) has exceeded 10 per cent since 2005-06. Notwithstanding such a high and sustained growth of the State, the estimated per capita income of the State in 2013-14 at current prices was only ₹ 33,954 (Economic Survey-Bihar, 2014-15) compared to national average of ₹ 80388 at current prices during the same year. 
Further, the problem of low per capita income in the State is compounded by wide variation in per capita incomes across the districts. As per estimates for per capita Gross District Domestic Product (GDDP) for 2011-12, the flourishing districts of the State viz., Patna, Munger and Begusarai had per capita GDDP of ₹63,063, ₹22,051 and ₹17,587, respectively. The variation between Patna and Munger is significant.There were 12 , out of 38 districts in the State, having per capita GDDP of less than ₹10000 (Economic Survey Bihar, 2014-15).

Importance and Potential of Agriculture in Bihar: Various experts and policy makers have appreciated and highlighted the importance and potential of agriculture development crucial for the economic development of the State. The Special Task Force constituted by the Government of India in 2008 on "Bihar's Agriculture Development: Opportunities \& Challenges" indicated in its preamble "The world experience suggests that agriculture sector has been the pre-cursor of economic growth process. Bihar cannot be an exception. Let prosperity be ushered in Bihar by bringing another farm revolution." Further, the views expressed in $3^{\text {rd }}$ Crop Summit of Bihar highlighted "Soon Bihar will become Punjab and second green revolution will start from these areas" (Ashok Gulati, 3rd Crop Summit). Similar views were expressed at the policy level which underscored the potential of agriculture development in Bihar by stating "We have seen the first green revolution, but it happened several years ago. Now it is the demand of time that there should be a second green revolution without any delay.And where is it possible? It is possible in eastern UP, Bihar, West Bengal, J harkhand, Assam, and Odisha" (Prime Minister's Speech,Times of India,29] une, 2015).

\section{Bringing Green Revolution in Eastern India (BGREI) Programme: A task forceconstituted by} the Government of India to make short and medium term recommendations for efficient management of water, power and other inputs as well as subsidy to maximise agricultural production on a sustainable basis suggested implementation of a programme of "Bringing Green Revolution in Eastern India"(BGREI) .The programme has been under implementation since 2010-11 in seven States including Bihar.

The BGREl programme identified low productivity of major crops of rice and wheat and low seed replacement ratio as the biggest constraints in agriculture development in the State. The strategies identified to overcome the constraints were use of hybrids with the technique of System of Rice Intensification (SRI) and System of Wheat Intensification (SWI) for increasing the productivity of rice and wheat. Another important strategy adopted was promotion of improved technology to enhance the productivity of maize and pulses.

\section{Initiatives of the Government of Bihar in Agriculture}

There are various stakeholders for the development of agriculture in the State and all of them have their due role. The State government has realised the importance of the sector and initiated steps in the right direction. The State embarked on an innovative approach 
for agriculture growth with the launching of 'Agriculture Road Map'in 2008. The approach put considerable emphasis on ensuring availability of certified seeds and the same were distributed at subsidised rate. Stress was also given on bio-farming, farm mechanisation and the new technique of SRI cultivation.

Buoyed by the success of its initiative, the State Government has prepared an 'Agriculture Road Map' for 2012-17 on the basis of wide consultations with experts and suggestions of farmers. The Report of the Expert Committee constituted by the State government was thoroughly discussed in a Kisan Samagam in February 2012 and the suggestions of farmers were taken into account. The 'Agriculture Road Map' so prepared by State government in 2012 enlists several initiatives to increase production and productivity of food crops in a cost-effective mannerand makes it a viablemeansof livelihood (Economic Survey-Bihar, 2014-15).

Keeping in view the importance of agriculture sector, the State government is making focused and sustained efforts by undertaking activities as per plan targets and made an expenditure of ₹4,805.33 crore for agriculture and allied sectors during $11^{\text {th }}$ Plan period surpassing the target of $₹ 3,672.73$ crore for the Plan period. It has also planned in a big way for ensuring improvement in the sector through planned development. A comparison of outlay of select States brings out the emphasis being laid by the State government in this regard (Table 4).

Table 4: Comparison of Outlay and Expenditure for $11^{\text {th }}$ and $12^{\text {th }}$ Five Year Plan for Agriculture and Allied Sectors of Select States (₹crore at current prices)

\begin{tabular}{lcccc}
\hline \multicolumn{1}{c}{ State } & \multicolumn{2}{c}{ Eleventh Plan } & Twelfth Plan & $\begin{array}{c}\text { Increase in Twelfth } \\
\text { Plan over Eleventh Plan } \\
\text { Expenditure (per cent) }\end{array}$ \\
\hline UttarPradesh & Outlay & Expenditure & Outlay & 72 \\
Bihar & $3,146.37$ & $14,164.8$ & 24,354 & 225 \\
Maharashtra & $9,5072.73$ & $4,805.33$ & 15,613 & 82 \\
Madhya Pradesh & $3,408.18$ & $10,636.4$ & 19,325 & 182 \\
West Bengal & $1,846.50$ & $3,057.09$ & 17,076 & 157 \\
All India & $94,670.21$ & $1,11,824$ & $2,26,500$ & 103 \\
\hline
\end{tabular}

Source:Twelfth Five Year Plan, 2012-2017 (Tables 12 \&13). 
It may be observed from Table 4 above that the State of Bihar has surpassed the target for the $11^{\text {th }}$ Plan period and proposed an outlay of $₹ 15,613$ crore for the $12^{\text {th }}$ Plan period indicating a whooping increase of 225 per cent over the expenditure made during $11^{\text {th }}$ Plan. The increase in allocation was not only the highest in the country but more than double the increase of 103 per cent envisaged at all India level.

Outcome of State Government's Efforts: State government's efforts led to a substantial and sustained growth of the State economy in recent years with meaningful contribution from agriculture/animal husbandry sector.The sector has registered a Compounded Annual Growth Rate (CAGR) of 13.2 per cent at current prices from 2010-11 to 2013-14. This turnaround is of great significance in the State which had CAGR of less than 2 per cent just a decade ago (year 2000-01 to 2004-05). Government of India also ap preciated the meritorious efforts in foodgrain production through Krishi Karman Award to Bihar for its contribution to production and productivity of rice in 2011-12 and for wheat in 2012-13. Incidentally, with the bifurcation of the State, the State has lost its industrial and mineral sectors to the newly carved State of J harkhand and agriculture has become the mainstay of Bihar's economy.

The growth in agriculture sector, as indicated earlier, came largely from increase in production and productivity of foodgrains with rice being the major contributor. The increase in rice production is largely attributable to efforts made by the State government for popularising "Sustainable Rice Intensification (SRI)" technique among farmers as about 50 per cent of area under rice was dependent on uncertain rain fall. The provision of State government's support for agricultural implements useful in local conditions has been another important reason for the growth.The introduction of'zero tillage method' and use of 'System of Wheat Intensification' technique have helped increase production of wheat in the State. Field demonstration arranged bythe State government was a major contributor to the increase in maize production in the State. The initiatives taken by the State government have paid off. The Twelfth Plan document of Government of India has also acknowledged the contribution of the State as it indicated that the "Rice yield growth was also higher in the Eleventh Plan than in any period after 1991, with Assam, Bihar,Chhattisgarh,East Uttar Pradesh and West Bengal contributing 80 per cent of this, again with growing awareness of conservation practices" (Twelfth Five Year Plan 2013, Government India, 2012-2017, Para 12.25).

\section{Role of Credit}

Although it is extremely difficult to make an accurate assessment of role of credit in supporting agricultural growth, credit is undoubtedly an enabling input which can influence agricultural GDP by use of variable inputs and investments in fixed capital supporting agricultural production. Bhalla and Singh (2010) suggest that institutional credit is indispensable for backward regions with low input and investment in agriculture.

A study undertaken by National Bank for Agriculture and Rural Development (NABARD) and Indira Gandhi Institute of Development 
Research (IGIDR), Mumbai, to assess the impact of agricultural credit on agricultural production during 1995-96 and 2011-12 has observed a credit elasticity of 0.574 to Agriculture GDP during the second phase of 2004-05 to 201112 in Bihar (NABARD, 2015). This means a 1 per cent increase in institutional credit flow to agriculture in current prices is associated with a 0.574 percent increase in agricultural GDP of the year expressed in current prices.

Importance of Credit from State's Perspective: In a State where per capita income is very low and the people do not have sufficient savings to invest, the need of resourcesup port is extremely important. This is particularly true of farm households where surplus is less because of low productivity.Agriculture requires adequate and quality inputs such as irrigation, seeds, fertilisers, farm equipment, professional extension services, etc., in time. The role of institutional credit assumes utmost importance under the circumstances, as it would provide the necessary wherewithal to the farmers to use modern techniques of agriculture necessary to increase productivity. However, the role of formal credit delivery system in the State of Biharhasnotbeen quite encouraging.

The capital intensive nature of modern agriculture has been established by now and the adoption of technology which is so essential in a State like Bihar is badly affected by the absence of suitable mechanism for provision of institutional credit to farmers. The role of institutional credit, inter alia, was also examined by the Special Task Force $(\mathrm{GOI}, 2008)$ constituted by the Government of India.The Task Force in its report observed, "A large number of farmers in Bihar are isolated from institutional credit sources. Even if somesources are available, the amount is inadequate and availability is not in time. This constrains farmers' adoption of technological practices."

Thetask force was particularly concerned with the inadequate availability of institutional credit to small and marginal farmers and observed "A large number of small and marginal farmers are not part of the institutional farm credit system. This needs to be given urgent attention."

\section{Institutional Credit and Its Outreach in Bihar:}

The State of Bihar is presently served by 35 commercial banks, 3 regional rural banks, one state cooperative bank and 22 central cooperative banks. The average population served per branch in Bihar is about 17200 as compared to national average of 12100 . The State had a total of 6297 branches as on 31 March 2015. Although the State accounted for about 9 per cent of the total population in the country, it had a share of less than 5 percent of the branches of commercial banks in the country.

In a State, which had lessthan 12 per cent of its population living in urban areas, 1196 branches (19 per cent) were located in urban areas and hence not engaged in any agricultural advances. The three RRBs had a sizeable number of branches in rural areas having 1618 out of a total of 3649 branches of all banks in rural areas. 22 public sector banks viz., SBI and its associates, IDBI and other commercial banks 
had1853 rural branches with SBI leading the group with 416 such branches. The cooperatives and a few private sector banks also had their branches in rural areas.lt would be interesting to make a comparison of branch network with neighbouring State of West Bengal where commercial banks (both public and private) had taken initiative to open the branchesin rural areas and had more than 2250 branches as in December 2014 compared to about 1870 branches of such banks in Bihar (SLBC website Bihar and West Bengal).

Notwithstanding the absence of adequate number of bank branches and a lot of emphasis on implementation of financial inclusion plan by banks as per Gol / RBI directives, the banks have lacked seriousness in opening of branches in the State of Bihar.The banks could not achieve theirtarget of opening of branches during 2013-14 and 2014-15 as they opened only 638 and 389 branches respectively against the target of opening of 750 and 600 branches during the concerned period. Incidentally, the State has 294 unbanked villages having population above 10000 in March 2015 (SLBC, Bihar Agenda and Minutes of 48 and 52 Meeting).The absence of adequate number of banking outlets in rural areas has deprived farmers of credit from institutional agencies and made them dependent on informal sources. This has partly led farmers to persist with obsolete means of technology in agriculture.The spread of branches of commercial banksin rural areas, thus, may be of great help to the State because of their better financial strength compared to other banking institutions.

Besides bank branches, nowadays banks provide an avenue of disbursement of funds through Automated Teller Machines (ATMs) at different locations. These ATMs enable the farmers to draw their funds at the time of their choice and their availability in different places help them avoid visiting bank branches. However, the number of ATMs in rural areas, primarily operated by public sector banks, was only 2172 making it difficult for agriculture households to avail of banking facilities beyond normal business hours of bank branches. In fact, most of the public sector banks viz., Central Bank of India, UCO Bank, Union Bank of India, Indian Overseas Bank, etc., did not have ATMs located with all their branches in rural areas. None of the RRBs have any ATM in rural area till March 2015.There was need for both public sector banks and RRBs to initiate efforts for establishing ATMs on a large scale in rural areas so as to enable farmers to avail of payment services near to their place and at the time of their choice.

\section{Credit Deposit Ratio and Per Capita Credit in} Bihar:The Credit Deposit (CD) ratio of banks is considered as an important indicator of the contribution of the banking system. It is interesting to note that the Eastern States of West Bengal and Odisha had CD ratio of 67 per cent and 56 per cent, respectively in March 2014 while the $C D$ ratio in Bihar even with an increasing trend during last five years stood at 44.03 per cent in March 2015. This was far below 
the accepted level of 60 per cent and national average of 78 percent. Further, the neighbouring States also had total credit utilisation in the State more than Bihar, with Odisha and West Bengal having credit utilisation of $₹ 0.76$ lakh crore and ₹ 3.07 lakh crore, respectively,compared to credit utilisation of ₹ 0.66 lakh crore in Bihar in March 2014 (Basic Statistical Returns 2014, RBI, Table 1.7).

The commercial banks are the most dominant players in the banking system of the country and Bihar is no exception to it. However, it is quite distressing to note that the $C D$ ratio of these banks in Bihar was lower than the State average at only 40.22 per cent as on 31 March 2015. As these banks had cornered lion's share of the deposit at ₹ 1.87 lakh crore (89 per cent) out of ₹ 2.11 lakh crore, any meaningful increase in $C D$ ratio of the State would require sustained and concerted efforts on the part of commercial banks in the State.

Further, there was wide variation in the $C D$ ratio among the districts and it is quite disturbing to observe that the districts like Buxar, Bhojpur, Siwan, Gopalganj and Madhepura which have large agriculture tracts generally had $C D$ ratio lower than the State average. In fact, the $C D$ ratio of most of these districts was less than 30 per cent.

It appears that Bihar has been among the most neglected States by the banking system in the country and this is one of the important reasons of the backward status of the State. As per data published by RBI, Statistical Tables Relating to Banks in India, 2012-13, the per capita credit of $₹ 4,580$ and perbranch credit of $₹ 1,030$ lakh in Bihar was the lowest in the country.Uttar Pradesh, the most populous State in the country and its Eastern Region having a lot of similarity with Bihar, had more than double per capita credit of Bihar.Therefore, a State that had shown sustained growth in its economy in recent years definitely deserves a better deal from the banking system.

Meagre Credit Allocation: The process of allocation of credittargets to the banks also needs to be relooked into by the SLBC. The size of annual creditplan does not appear to truly reflect the potential and requirements of the State having population of more than 10 crore and gross sown area of 76.47 lakh hectares. The State Annual Credit Plan (ACP) target of ₹ 0.74 lakh crore (includes Non-Priority sector) and target of agriculture and allied activities at $₹ 0.36$ lakh crorefor 2014-15 worksout to lessthan ₹ 6,800 per capita credit. At this rate of allocation of credit by banks, Bihar may require more than a decade to lose its backward status with lowest per capita credit in the country. Definitely, the State and the nation cannot afford such a long wait. This requires focused attention by all concerned. The Hon'ble Chief Minister of the State has also expressed his dissatisfaction over the size of annual credit plan of the State (Minutes of $52^{\text {nd }}$ SLBC Meeting of Bihar, 2015).

\section{Status of Cooperatives in Bihar}

Notwithstanding the increasing share of commercial banks in agricultural credit, the cooperatives have always been reckoned as one of the most suitable structures for dispensation of agricultural credit.The proximity 
and outreach of cooperatives have always endeared the farming community. However, financial health of cooperative credit structure in the State is in a very bad shape. The long-term cooperative credit structure, through its term loans for agriculture and allied activities, has always played an important role in capital formation in agriculture. The structure is defunct in the State for quite some time.

Unfortunately, the financial health of the short-term cooperative credit structure is also not in a good shape in Bihar. Although, all the District Central Cooperative Banks (DCCBs) in the State have been licensed by Reserve Bank of India (a recognition of their activities as banks) in recent years, there are serious issues relating to governance, manpower, managerial competence and financial health of these institutions. All this has affected their role in dispensation of agricultural credit and their role and share has been shrinking. The cooperative structure which disbursed about ₹423 crore of agriculture credit in 2010-11 forming 4 per cent of total credit has shrunk to the level of about 2 per cent of total agricultural credit in 2013-14. The Primary Agriculture Cooperative Societies (PACS), which had enrolled more than 10 lakh members, had a borrowing membership of hardly about 10 per cent. Therefore, serious efforts are a must to revive the cooperative credit structure to its past glory in the State.

\section{RRBs - A Ray of Hope in Bihar}

Fortunately, the performance of three regional rural banks providesa ray of hope from the banking system. The percentage of achievement of allocated targets of agriculture credit disbursement among all the agencies was highest in respect of RRBs in the State.RRBs registered an achievement of ₹ 13,125 crore (99 per cent) and ₹ 16,185 crore (102.24 per cent) against allocated target of $₹ 13,260$ crore and $₹ 15,831$ crore during the years 2013-14 and 2014-15, respectively. The performance of RRBs was quite impressive in respect of disbursement to crop loan and issue of Kisan Credit Cards (KCCs). By March 2015, the number of KCCs sanctioned by RRBs was 12.62 lakh, which exceeded the number of KCCs sanctioned by commercial banks at 10.51 lakh. The RRBs have also provided better credit linkage to J oint Liability Groups (JLGs) and Self-Help Groups (SHGs), where credit has been used primarily for agriculture, than the commercial banks in Bihar.

\section{Crop Loan Disbursement by Agencies}

As per census 2011, there are around 71.96 lakh cultivators in Bihar. However, by March 2015, the cumulative number of kisan credit cards sanctioned for providing crop loan was only ₹24.71 lakh. The share of commercial banks in the issue of KCCs was only 42.5 per cent. Most of the KCCs were issued by three RRBs in the State as mentioned earlier.Agency-wise details of disbursement of crop loan during last 3 years are given in Table 5 . 
Table 5: Agency-wise Disbursement of Crop Loan during 2012-2015 (₹lakh)

\begin{tabular}{lcccc}
\hline \multicolumn{1}{c}{ Agency } & $2012-13$ & $2013-14$ & $2014-15$ & $\begin{array}{c}\text { \% of total } \\
\text { during 2014-15 }\end{array}$ \\
\hline Commercial banks & 733482 & 850202 & 963789 & 48.5 \\
RRBs & 680784 & 829997 & 985016 & 49.6 \\
Cooperative banks & 32820 & 30754 & 36180 & 1.9 \\
\hline Total & 1447086 & 1710953 & 1984985 & 100.0 \\
\hline
\end{tabular}

Source: SLBC and NABARD, 2012-13, 2013-14 and 2014-15.

Table 5 shows that the share of RRBs in disbursement of crop loans (49.6 per cent) exceeded the share of commercial banks ( 48.5 per cent) although they had lesser share in number of bank branches as mentioned earlier in the paper.

\section{The Way Forward}

It is widely accepted that a large number of small and marginal farmers have not been able to avail of credit from formal credit system. Keeping this in view, the suggestion of Dr.Sen Committee on Agriculture Production in Eastern India (1984), although made more than three decades ago, for provision of a small 'minikit' containing required quantity of seed, fertiliser and even pesticide for specific farm size, still holds good. The Special Task Force (Gol, 2008) also while recommending the same indicated "The programme was taken up earnestly by West Bengal for summer rice during late eighties and early nineties with very successful results. Under present Bihar conditions, introduction of this programme both for rice and wheat is recommended."The State government may consider the recommendation for implementation as small and marginal farmers play an important role in the agriculture development of the State.
There is a need for separate strategy to bring the marginal farmers into the institutional fold of credit delivery as they operate more than 90 per cent of agricultural holdings in the State. The existing system and procedures of provision of institutional credit have not helped the marginal farmers avail of credit facilities from them. Further, there are a large number of sharecroppers / tenants who are outside the purview of the formal credit system. Reserve Bank of India has issued guidelines in the past advising banks to accept certificates provided by local administration / panchayati raj institutions regarding the cultivation of crops in case of loans to landless labourers, sharecroppers and oral lessees. In view of the difficulties faced in obtaining such certificates, the procedure was further relaxed in 2008 and an affidavit submitted by landless labourers, sharecroppers and oral lessees giving occupational status (i.e., details of land tilled / crops grown) is to be accepted for loans up to ₹50, 000 (RBI 2008).

Keeping in view the need for allocating adequate credit to small and marg inal farmers, RBI has revised its guidelines on priority sector in April 2015 for commercial banks. These guidelines require the banks to achieve a target of 7 per cent by March 2016 and 8 per cent by 
March 2017 in respect of their lending to small and marginal farmers. All-out efforts must be made to seize this opportunity through sustained efforts by banks and effective monitoring by RBI, NABARD and State government to ensure achievement of these targets.The State Level Bankers'Committee may, in consultation with State government, also devise a simple and common application form, as also the format of affidavit to be adopted by all the banks in the State for financing to sharecroppers/tenants.

Besides individual loans to small and marginal farmers, efforts may be made to extend credit to these farmers through the mechanism of Self-Help Group (SHG) and J oint Liability Group (JLG). The banks may be provided suitable target for coverage of farmers through these means.

The quantum of crop loan issued by banks is based on the scale of finance fixed by the District Level Technical Committee for various crops grown in the district. There is a wide variation in the scale of finance adopted by banks. For instance, the scale of finance fixed for paddy for financing during 2014-15 in Gopalganj and East Champaran districts was only ₹32,900 and ₹35,000 per ha, respectively, compared to $₹ 60,500$ per ha. $₹ 65,000$ per ha in Saran and Vaishali districts, respectively.All these districts fall under same agro-climatic region. There is a need to ensure fixation of scale of finance in tune with the cost of cultivation and the State government and State Level Bankers Committee (SLBC) may look into this aspect seriously.

The process of credit allocation to banks under Annual Credit Plans (ACP) must take into account the potential of agriculture development so that adequate credit targets are allocated to banks in all the districts. There is a need to provide for adequate credit to all classes of farmers in the district so as to realise full potential of agriculture. The district level authorities of State government must play a proactive role in this exercise.

The performance of public sector commercial banks having lion's share of deposit,maximum rural outlets and also having the responsibility of playing a lead role in agriculture and rural development under lead bank scheme is of utmost importance for the development of State. A high-power committee of Government of India, RBI, NABARD, State Government and SLBC may be constituted for this purpose for intensive monitoring of various parametres which influence the provision of credit by commercial banks for agriculture. Also, it is important to mention that the potential role of cooperative credit structure has not been harnessed adequately. Due to its wide network through primary agricultural cooperative credit societies, it is worthwhile to make concerted efforts to make them play a greater role in dispensation of agricultural credit to farmers in Bihar.

In conclusion, it is stated that Bihar has the potential to make meaningful contribution to the second green revolution in the country. The State government has initiated some measures to unlock the potential. However, the institutional credit agencies must play their role in the right earnest to secure agricultural prosperity in the State which is so crucial for its development and its contribution to national development. 


\section{References}

1. Bhalla, G.S. and Gurmail Singh (2010), "Growth of Indian Agriculture: A District Level Study", Planning Commission, Government of India. Available at http://planningcommission.nic.in/ reports/sereport/ser/ser_gia2604.pdf.

2. Government of Bihar (2015), "Economic Survey 2014-15", Finance Department, Patna http:// finance.bih.nic.in/Documents/Reports/Economic-Survey-2015-EN.pdf.

3. Government of India, "Agriculture Census 2010-11, State-wise Number and Area of Operational Holdings for All Social Groups and Marginal Size Groups", Ministry of Agriculture and Cooperation, http://agcensus.nic.in/document/agcensus2010/agcen2010rep.htm

4. Government of India (2008), "Bihar's Agriculture Development: Opportunities \& Challenges - A Report of the Special Task force on Bihar",http://planningcommission.gov.in/aboutus/taskforce/ tsk_adoc.pdf

5. Government of India (2013), "Twelfth Five Year Plan (2012-2017)", Economic Sectors, Volume II, Planning Commission, SAGE Publications India Pvt Ltd, New Delhi, www.sagepub.in (Table 12 \& 13).

6. Gulati, Ashok, (2013), “3 ${ }^{\text {rd }}$ Crop Summit in Bihar”, Sept. 2013, Reported in Economic Times, http:// articles.economictimes.indiatimes.com/2013-09-17/news/42148746_1_farmers-crop-productionminimum-support-price

7. Government of India (2014), "Handbook of Horticulture”.

8. NABARD (2015),"Productivity of Agriculture Credit in India - Assessing the Recent Role of Institutional Credit to Agriculture in India Using State level Data", Mumbai.

9. RBI (2008), Circular on Simplification of Lending Procedures for Crop Loans, RBI/ 2008-09/ 140. RPCD.PLFS. BC. No. 22 /05.04.02/ 2008-09 dated 26 August 2008.

10. Reserve Bank of India (2014), "State-wise Outstanding Credit of Scheduled Commercial Banks According to Place of Sanction and Utilisation, March 2014,Table1.7, https://rbidocs.rbi.org.in/rdocs/ Publications/PDFs/107T9698DE69B4D043FF9D583FE4322DEBF0.PDF

11. Sen, S R (1984), “Dr. Sen Committee on Agriculture Production in Eastern India”.

12. State Level Bankers Committee, Bihar, 2013, Agenda and Minutes of 45th SLBC Meeting, http:// slbcbihar.com/

13. State Level Bankers Committee, Bihar, 2014, Agenda and Minutes of 48th SLBC Meeting, http:// slbcbihar.com/

14. State Level Bankers Committee, Bihar, 2015, Agenda and Minutes of 52 ${ }^{\text {nd }}$ SLBC Meeting, http:// slbcbihar.com/

15. State Level Bankers Committee, Odisha, As on 12 July 2015, http://ww w.slbcorissa.com/BNS.htm State Level Bankers Committee, West Bengal, As on 12 July 2015 http://www.slbcbengal.com/ ImplementationAnnualCreditPlan.asp 